\title{
An Analytical Study of Agricultural Vocational Tendencies and their Relationship to some Personal and Environmental Factors (A Study for Students of the Faculty of Agriculture, Mansoura University) \\ Raghda H. M. Salem
}

Department of Agricultural Extension and Rural Society, Faculty of Agriculture, Mansoura University

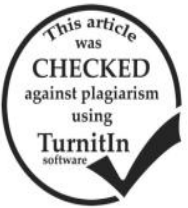
دراسة تحليلية للميول المهنية الزراعية وعلاقتها ببعض العوامل الثخصية والبيئية (دراسة لطلاب كلية الزراعة جامعة المنصورة)

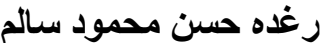
قسم الإرشاد الزراعى والمجتمع الريفى-كلية الزراعة- جامعة المنصورة الملخص

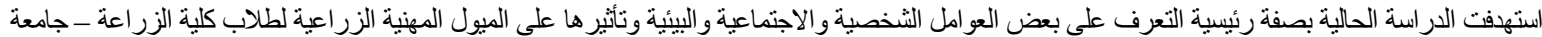

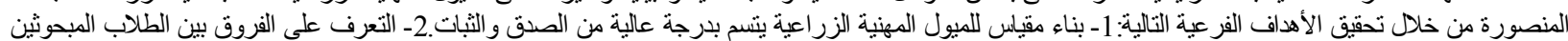

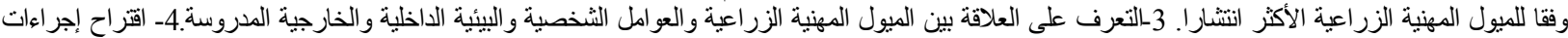

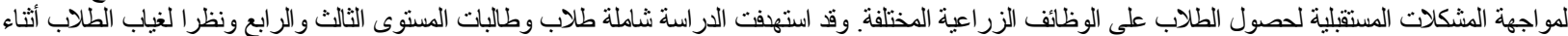

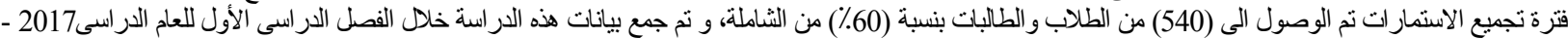

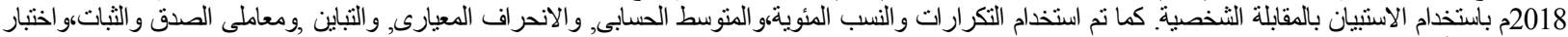

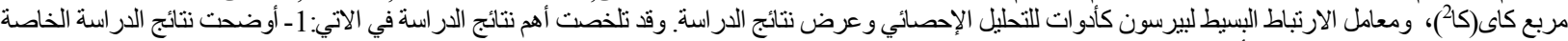

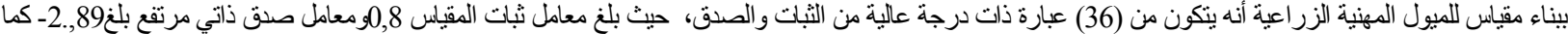

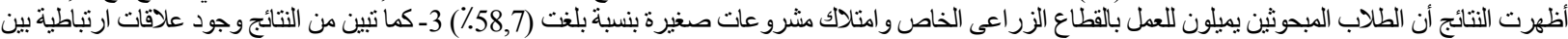

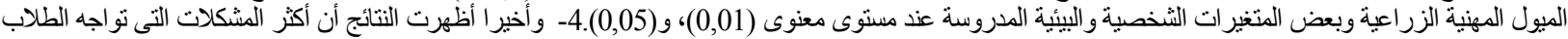

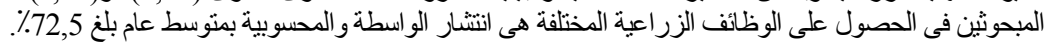

ـالميل الإقناعى: ويميل أصحاب هذاب الميل الى إقى إقناع الآخرين بأفكار ومشروعات جديدة.

ـللميل للخدمة الاجتماعية: يوجدة هذوة هذا الميل عند الأفراد الذين يميلون

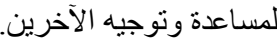

ب تصنيف سترونج" Strong Vocational Interest": صنف الأن

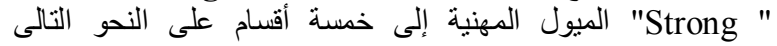

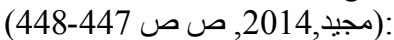

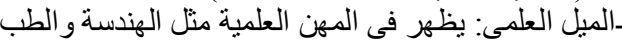

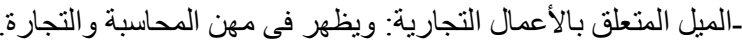

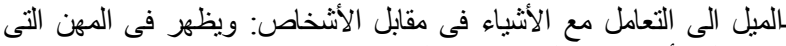
تنتاول الأشياء بالتعديل و التغيير منل التجارة والطيل الطباعة.

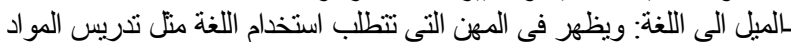
الاجنماعية و المحاماه و التأليف.

ـالميل للتعاون مع الناس ويظهر فئل فئ المهن التى تهنم بالأشخاص مثل

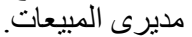

جتصنيف هولآد "Holland's Model of Vocational Interests": يرى هو لاند أن الأشخاص يميلون الثيل المهن المختلفة حسب شخصباتهم فهو

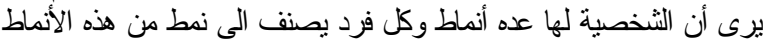

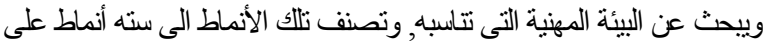
النحو التالى: (Chemeli,2013,p.385) و) Ketal.,2016) (pp.102-103

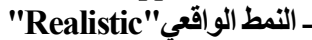
بمثاز أفراد هذا النمط بأنهم يجيلون التعامل و التفاعل مع الأثياء المادية،

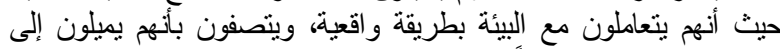
النشاطات التي تنطلب تتاسقًا حركيًاو مهارة جسمية.

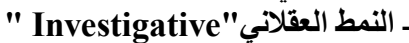

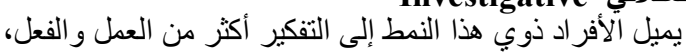

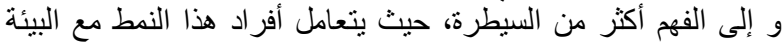

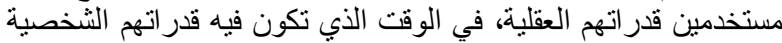

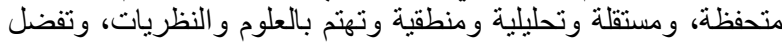

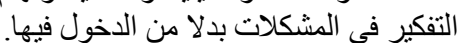

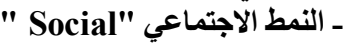
إن الأشخاصَّ من هذا النوع يميلون إلى التعامل و التحدث مع الآخرين،

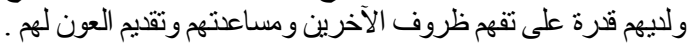

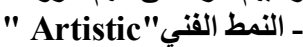

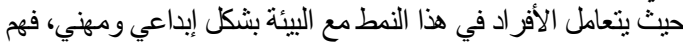

يمتازون بشخصية حسية، مبدعة تعبيرية وغير تقلينية.

\section{المقدمة}

تعد مرحلة التعليم العالى من المر احل التعليمية المهمة في حياة الطلب؛

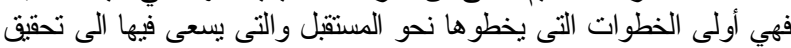
أحلامه وأهدافه المستقلية على أفضل الفطل ما يكون. Nauta,2010,p.11)

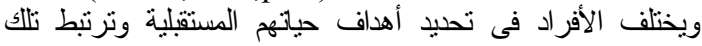

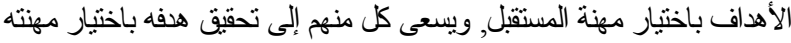

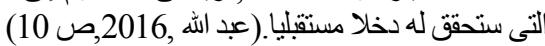

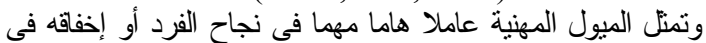

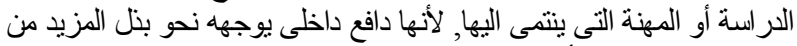

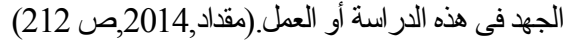

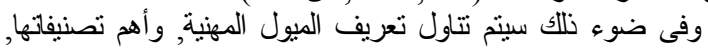

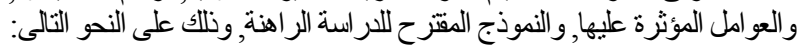
اولا: تعريف الميول المهنية:

يرى "خياطة" (2015,ص 10) نقلا عن (Strong,1981) أنها مجموعة الخيار ات التى يفاضل بها الثخا الثخص من بين الأنشطة التى ينخرط فيها, حيث يفضل بعضهاوينبذ الأخرى.

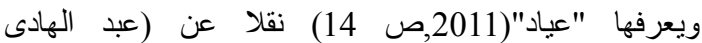
والعزه,1999) انها مجموعة استجابات القبول التى تتعلق بنشاط مهنى (عنى

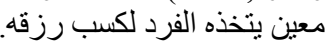

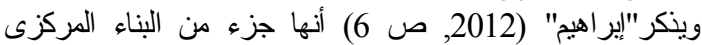

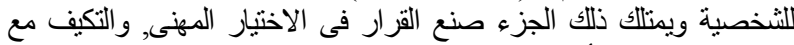

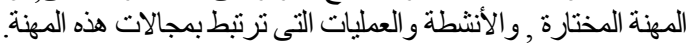
ثانيا: تصنيف الميول المهنية والانية

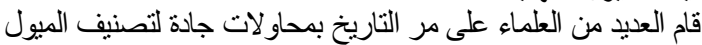

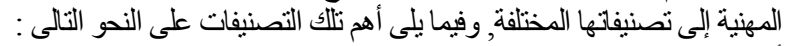

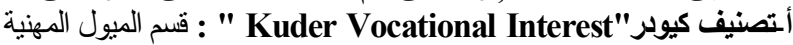

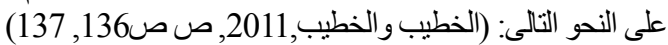
ـالميل الخلوى : يفضل أصحاب هذاب الميل للعمل فى نربية الحيوانات

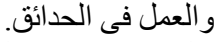

ـ الميل الميكانيكى: يفضل الصفل أصحاب هذا الميل العمل فى الآلات الميكانيكية.

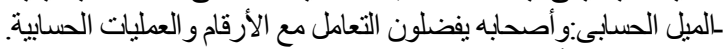

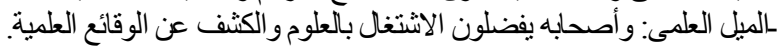

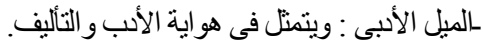

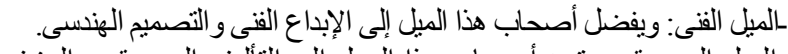

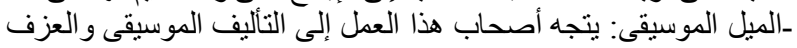

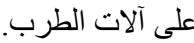

ـالميل الكتابى: وأصحابه يفضلون التعامل مع الورق على التعامل مع الأفراد. 
رابعا: النموذج التصورى للار اسة الراهنة:

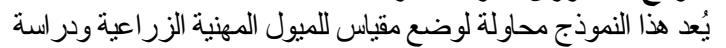

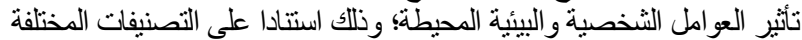

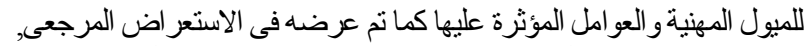

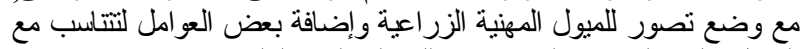

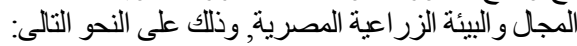

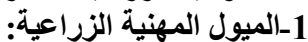

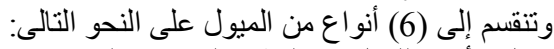

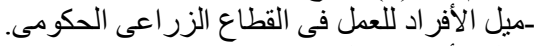

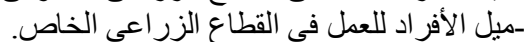

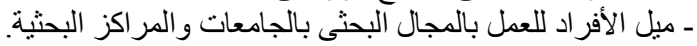

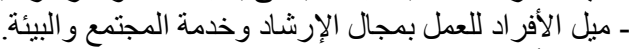

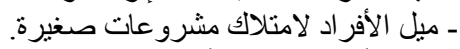

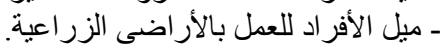

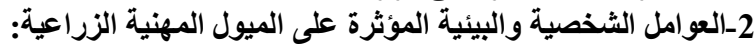

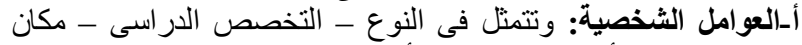

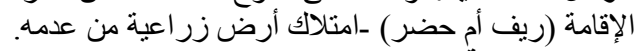

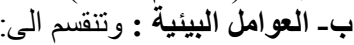

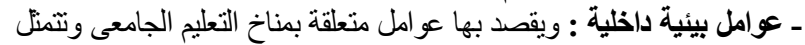

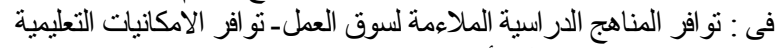

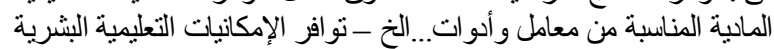

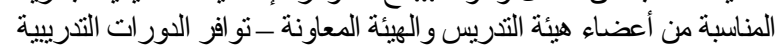
الملاعهة لسوق العمل - تأثير العلاقات الطلايية الجامعية.

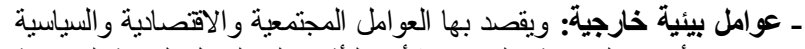

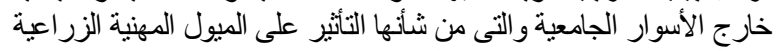

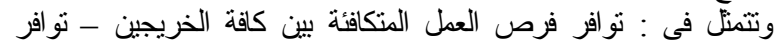

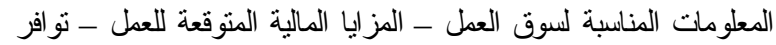

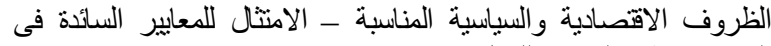
المجتمع (نظره المجتمع للعمل).

ويوضح شكل (1) الأبعاد المختلفة للنموذج التصورى للار اسة الر اهنة
ـ النمط المغامر " Enterprising"

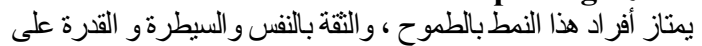

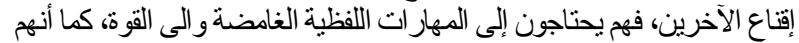

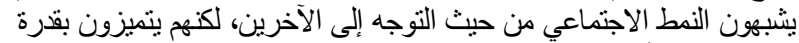

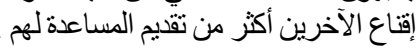

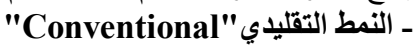

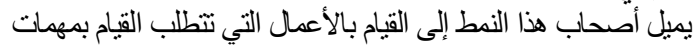

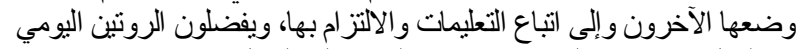

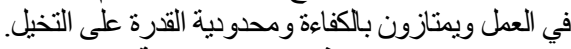
ثالثا:العوامل المؤثرة فى الميول المهنية المئية

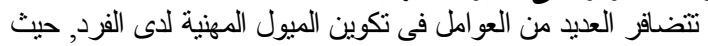

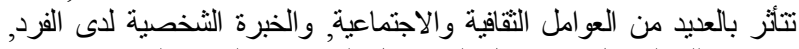

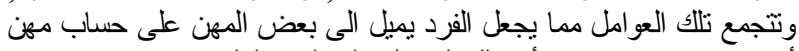

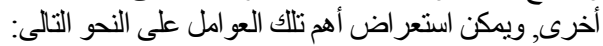

(Ohiwerei\& Nwosu,2009,pp.2-3)

(Aljojo,2016,p.2016)

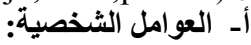

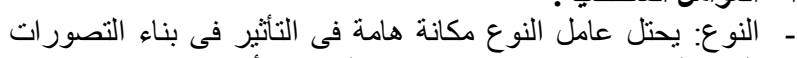

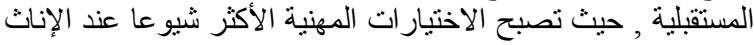
اقل اختيار أعند الذكور و العكس.

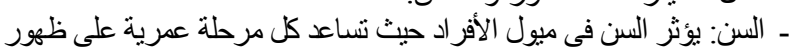

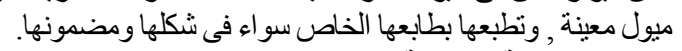

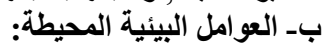

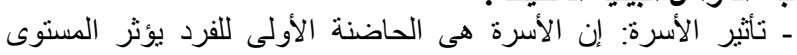

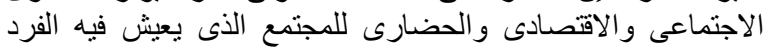
على اختياره للوظائف في الإنى المستقبل.

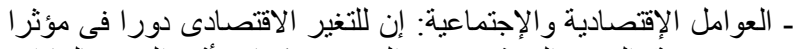

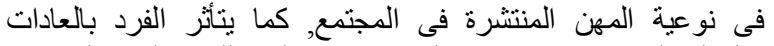

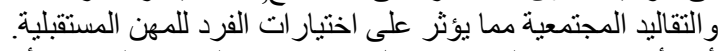

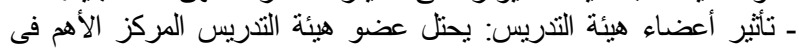

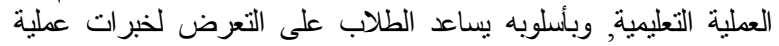
و اقعية لتحفيز الطلاب وتعزيز إحداث التغير ات السلوكية لليهم.

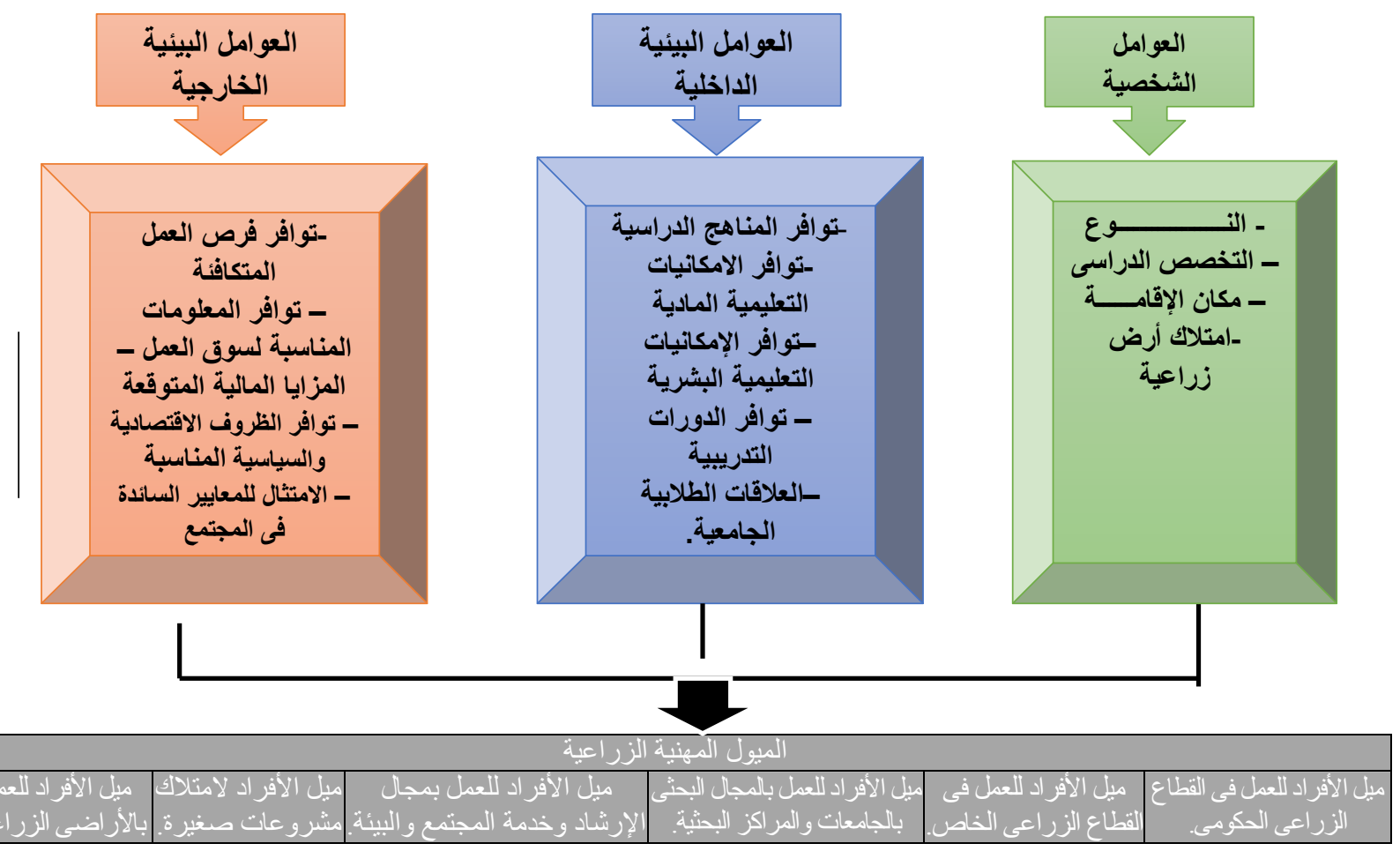

شكل 1. الأبعاد المختلفة للنموذج التصورى للاراسة الراهنة

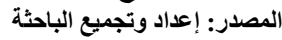

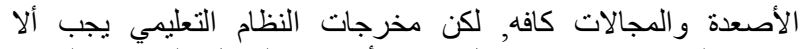

تقتصرعلى جوانب محددة بل يجب النب أن تمند لنتمل الجوانب النب المهنية

بعتبر "النظام التعليمي أساس التطور والتقام في مجالات الحياة

المشكلة البحثية

كافة, فمخرجات النظام التعليمي تشكل اساسا لرفعة المجتمع أو تخلفه في و التقنية. 


\section{J. Agric. Econom. and Social Sci., Mansoura Univ., Vol. 9(4), April, 2018}

المهنية الزراعية يحتوى على (45) عبارة لتحقيق الهف البحثى الأول , اما

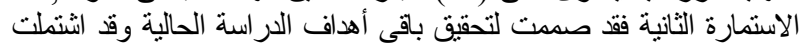

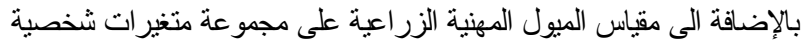
وبيئية داخلية وخار جية. جدول 1. توزيع الطلاب المبحوثين وفقا للخصائص الشخصية

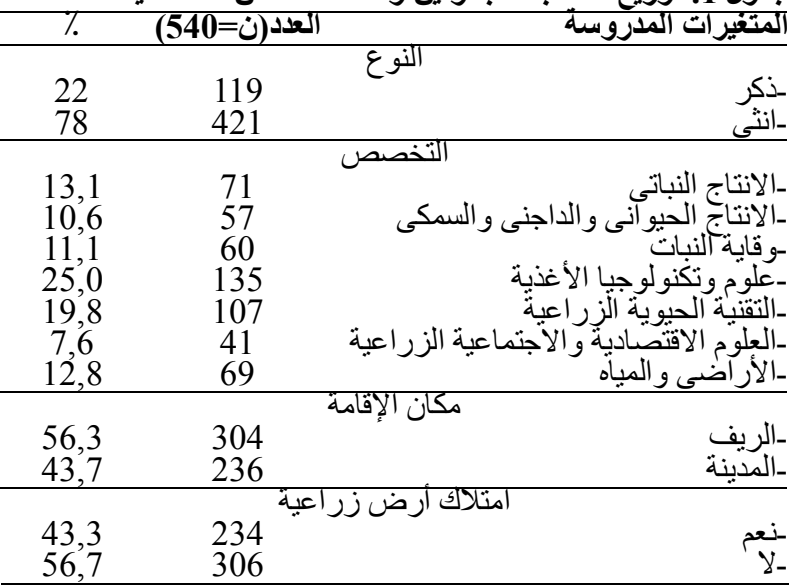

المصدر: استماره الاستبيان 5- - 5 المعالجة الكمية للبيانات:

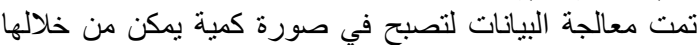

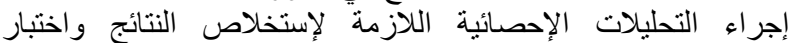
الفروض، وذللك علي النحو التالي: الإدية

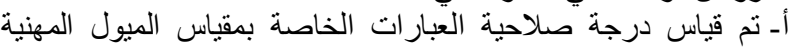

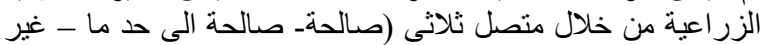

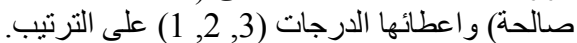

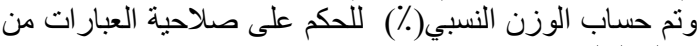

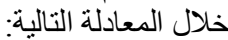

الوزن النسبي (\%) = عدد المبحوثين في كل فئة × الوزن النسبي المقابل لكل فئة $100 \times$

\section{إجمالي عدد المبحوثين × اكبر وزن المبن}

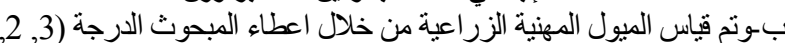

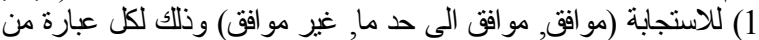

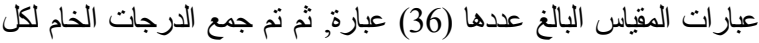

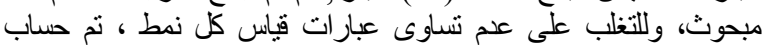

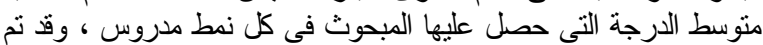

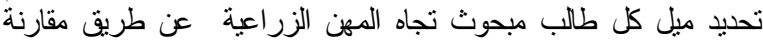

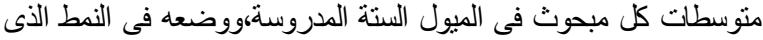
حصل فيه على أعلى متوسط دورجات.

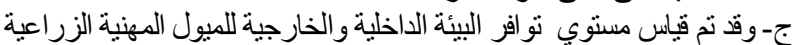

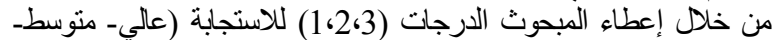
ضعيف) علي الترنيب.

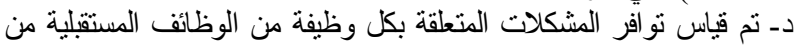

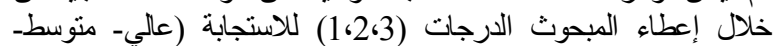
ضعيف) علي الترنيب.

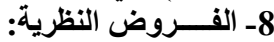
الفرض النظري الأول: توجد فروق النزبة ذات دلالة إحصائية بين الميول

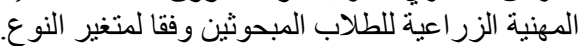

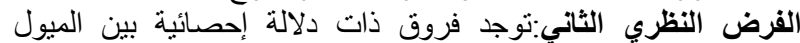

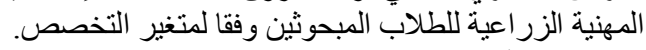

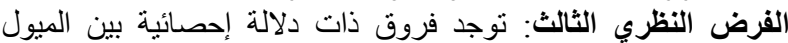

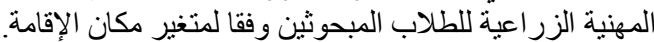

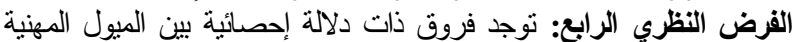

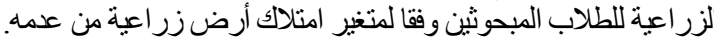

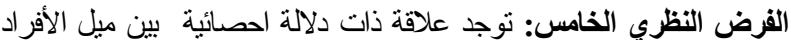

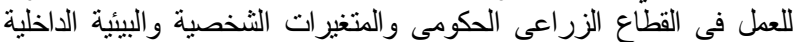
و الخارجية المدروسة. الفرض النظري السلاس: توجد علاقة ذات دلالة احصائية بين ميل الأفراد

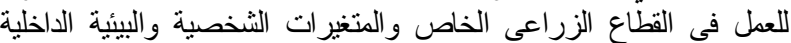
و الخارجية المدروسة.
وتعد مهنة المتتقلل من الأمور التى يهتم بها الطالب الجامعى لتحقيق

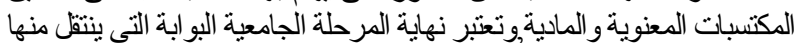

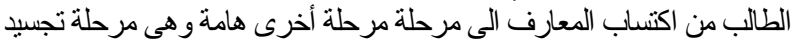

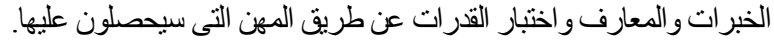

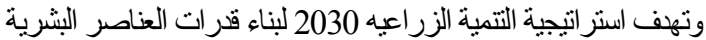

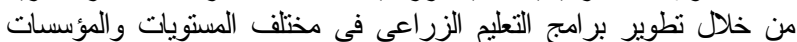

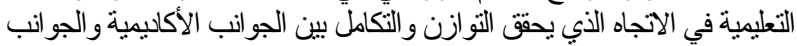

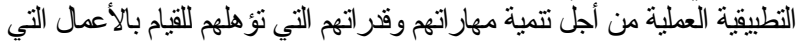

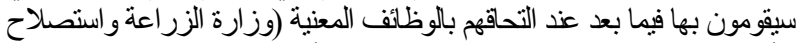
الأراضي، 2009، ص 104 104). ومن هنا تبرز أهمية الميول المهنية في اختيار

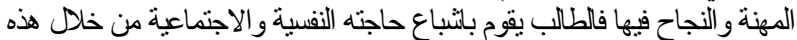

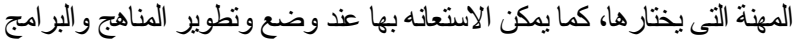

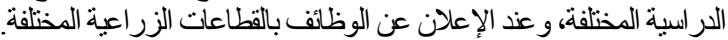

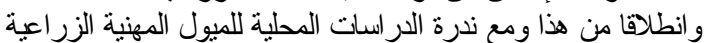

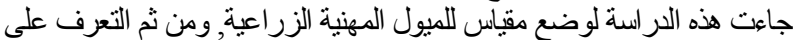

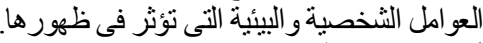

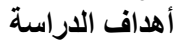

استهوت الدراسة بصورة رئيسية التعرف على بعض العو امل الثخصية

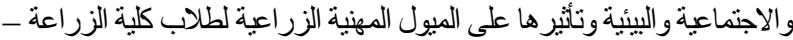

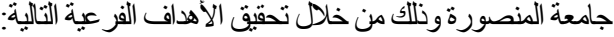

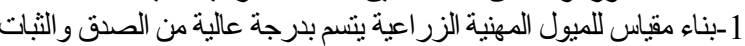

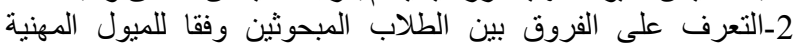
الزر اعية الأكثر انتشار ا.

3-التعرف على العلاقة بين الميول المهنية الزر اعية و العو امل الثخصية والبيئية الداخلية والخارجية الددروسة.

4-افتراح إجراءات لمواجهة المشكلات المستقلية لحصول الطلاب على المئي الوظائف الزر اعية المختلفة.

\section{الطريقة البحثية}

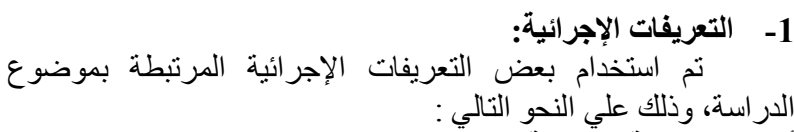

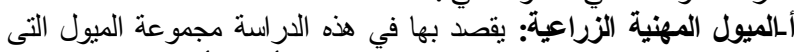

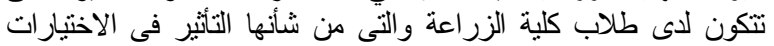

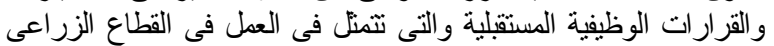

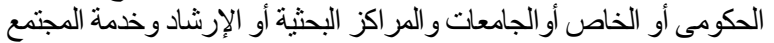

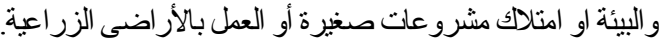

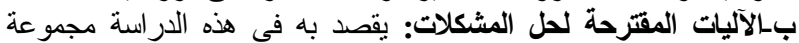

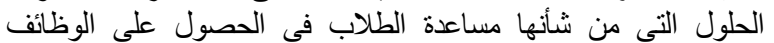

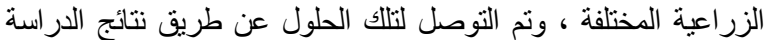

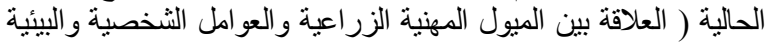

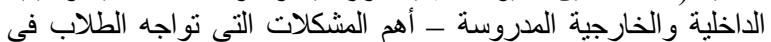

الحصول على الوظائف الزر اعية المختلفة).

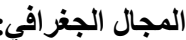

تم إجراء الدراسة الميدانية بكلية الزراعة - جامعة المنصورة باعتبار ها محل عمل الباحثة.

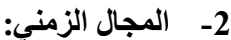

تم جمع الييانات اللازمة لاختبار صلاحية مقياس الميول المهنية

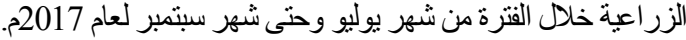

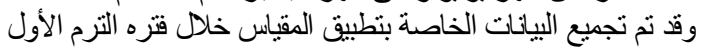
اللعام الدراسى 2017-2018. - 2018.

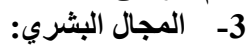

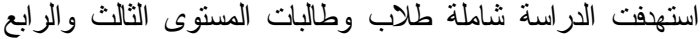

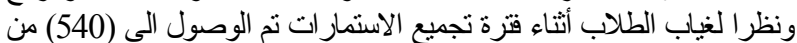

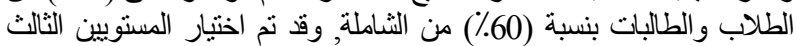

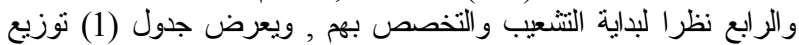

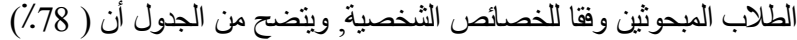

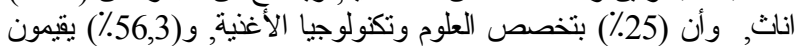

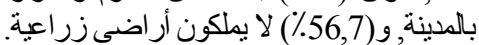
4- أدوات جمع البيانات:

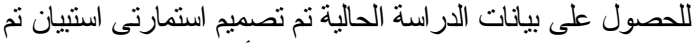

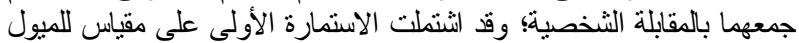


1- الصنق الظاهري:Face Validityأوضحت التنائج أن عبار ات مقياس الميول

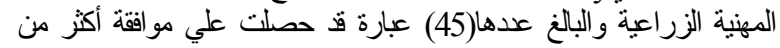

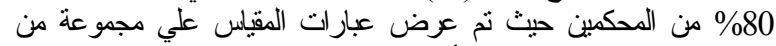

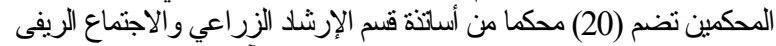

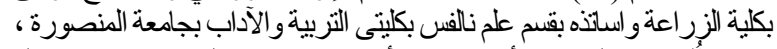

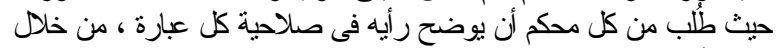

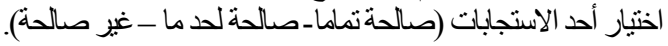

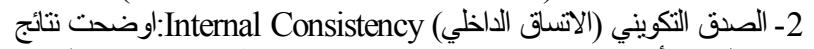

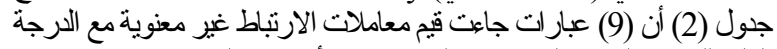

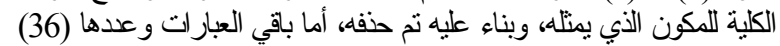

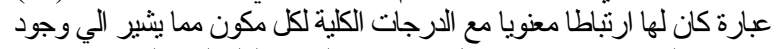

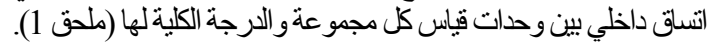

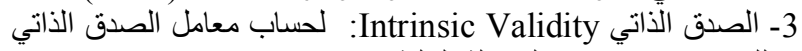

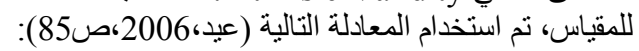

معامل الصدق الذاتى=

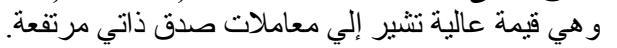

ب- ثبات المقياس Scale Reliability: لتحديد معامل ثبات المقياس تم استخدام معادلة كرونباخ

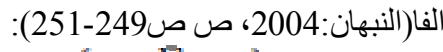

$$
\alpha=\frac{n}{n-1} \times\left\{1-\frac{2 s \times 2}{s \times 2}\right\}
$$

= معامل ثبات المقياس

n

政 $=5 x 2$

\$x2

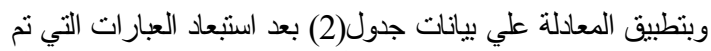

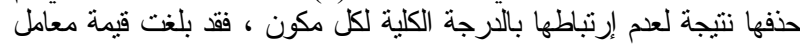

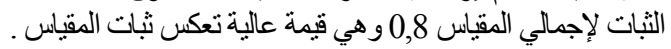

القرض النظري السلبع : نوجد علاقة ذات دلالة احصائية بين ميل الأفراد

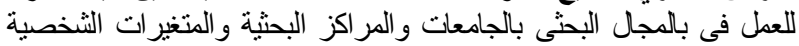

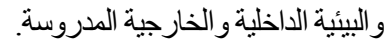

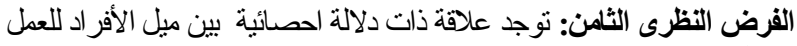

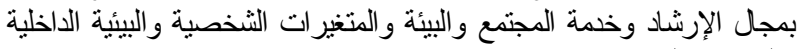
و الخارجية المدروسة.

الفرض النظرى التاسع: توجد علاقة ذات دلالة احصائية بين ميل الأفراد لامتلاكك

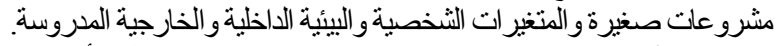

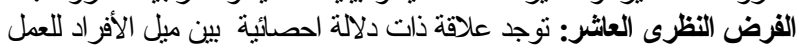

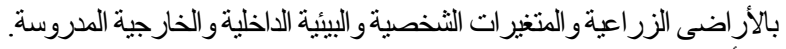
9ـ أدوات التحليل الإحصائي:

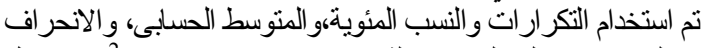

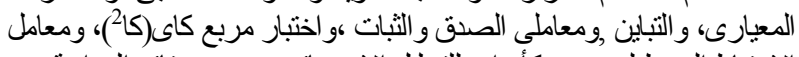

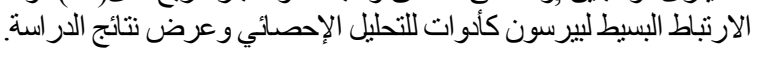

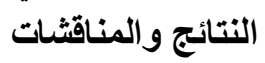

اولاً: نتائج اختبارات صلاحية مقياس الميول المهنية الزراعية

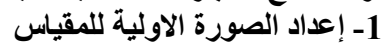

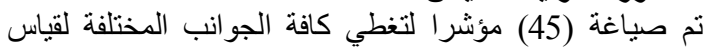

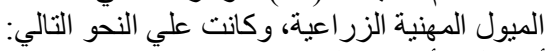

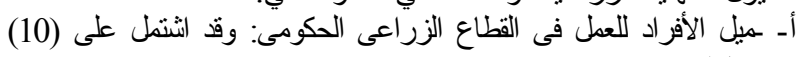

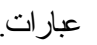

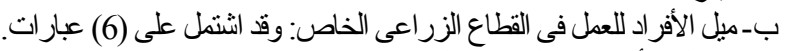

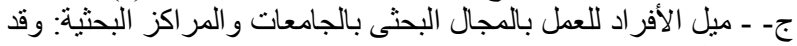

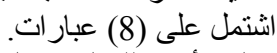

د-- ميل الأفراد للعمل بمجال الإرشاد (8) وخدمة المجتمع والبيئة: وقد اشتمل على (7) عبار ات.

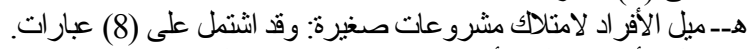

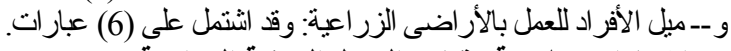

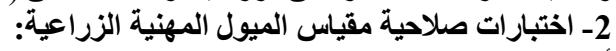
أـ صدق المقياس Scale Validity

وللتحقق من صدق المقياس تم استخدام ثلاثة أنواع من الصدق

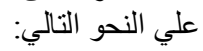

جدول2. معاملات الاتساق الداخلى لعبارات مقياس الميول المهنية الزراعية

\begin{tabular}{|c|c|c|c|c|c|c|}
\hline التسلسل الجديد للعبارات & معامل الاتساتّ الداخلى (r) & التباين & الاتحراف المعيارى & المتوسط الحسابي & رقم العبارة & الميول المهنية الزراعية \\
\hline ------- & 0,032 & 0,134 & 0,366 & 2,85 & 1 & \multirow{5}{*}{ ميل الزراعى الحكومى للعمل فى القطاع } \\
\hline 1 & ارتباط تام & 0,0 & 0,0 & 0,0 & 2 & \\
\hline 2 & $* * 0,609$ & 0,197 & 0,44 & 2,75 & 3 & \\
\hline 3 & $* * 0,697$ & 0,239 & 0,48 & 2,65 & 4 & \\
\hline 4 & ارتباط تام & 0,0 & 0,0 & 0,0 & 5 & \\
\hline -------- & 0,368 & 0,050 & 0,22 & 2,9 & 6 & \multirow{5}{*}{ الزيل الأفى الحكومى للعمل فى القطاع } \\
\hline 5 & $* * 0,688$ & 0,168 & 0,41 & 2,8 & 7 & \\
\hline ----- & 0,289 & 0,134 & 0,366 & 2,85 & 8 & \\
\hline ----- & 0,076 & 0,095 & 0,30 & 2,9 & 9 & \\
\hline 6 & ارتباط تام & 0,0 & 0,0 & 0,0 & 10 & \\
\hline 7 & ارتباط تام & 0 & 0 & 0 & 11 & \multirow{6}{*}{ الزراعى الأفراد للعمل فى القطاع } \\
\hline 8 & $* * 0,87$ & 0,197 & 0,44 & 2,75 & 12 & \\
\hline 9 & ارتباط تام & 0,0 & 0,0 & 0,0 & 13 & \\
\hline 10 & ارتباط تام & 0,0 & 0,0 & 0,0 & 14 & \\
\hline 11 & $* * 1,0$ & 0,463 & 0,68 & 2,6 & 15 & \\
\hline 12 & $* * 0,8$ & 0,134 & 0.366 & 2,8 & 16 & \\
\hline ------ & 0,03 & 0,050 & 0,22 & 2,9 & 17 & \multirow{8}{*}{ بالّامعات الأفر اد للعمل باكز البحتية البحثى } \\
\hline 13 & $* * 0,67$ & 0,197 & 0,44 & 2,7 & 18 & \\
\hline 14 & $* * 0,67$ & 0,239 & 0,48 & 2,8 & 19 & \\
\hline 15 & ارتباط تام & 0,0 & 0,0 & 0,0 & 20 & \\
\hline & 0,188 & ,095 & 0,30 & 2,9 & 21 & \\
\hline 16 & $* * 0,716$ & 0,168 & 0,41 & 2,8 & 22 & \\
\hline 17 & $* * 0,622$ & 0,095 & 0,30 & 2,9 & 23 & \\
\hline 18 & ارتباط تام & 0,0 & 0,0 & 0,0 & 24 & \\
\hline 19 & $* * 0,69$ & 0,095 & 0,30 & 2,9 & 25 & \multirow{7}{*}{ وخدمة المجتمع و البيئة اللعمل الإرشاد } \\
\hline 20 & $* * 0,79$ & 0,050 & 0,22 & 2,9 & 26 & \\
\hline---- & 0,171 & 0,050 & 0,22 & 2,9 & 27 & \\
\hline 21 & ارتباط تام & 0,0 & 0,0 & 0,0 & 28 & \\
\hline 22 & $* * 0,69$ & 0,095 & 0,30 & 2,9 & 29 & \\
\hline 23 & ارتباط تام & 0,0 & 0,0 & 0,0 & 30 & \\
\hline -------- & 0,312 & 0,134 & 0,366 & 2,8 & 31 & \\
\hline
\end{tabular}




\section{J. Agric. Econom. and Social Sci., Mansoura Univ., Vol. 9(4), April, 2018}

المبحوثين وفقا لمتغبر النوع، و لاختبار هذا الفرض تم استخدام اختبار(كام) ، وقد

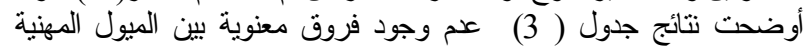

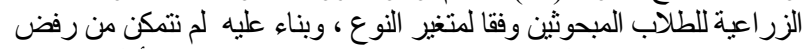

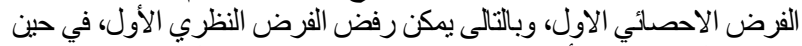

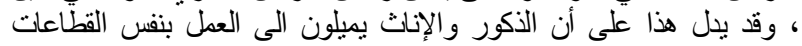

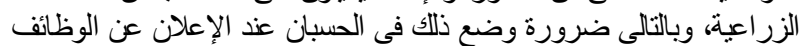
الز الزراعية بالقطاعات المختلفة. ب-الفروق بين الميول المهنية الزراعية للطلاب المبحوثين وفقا لمتغير لاختبار صحة الفرض النظري الثانى نم صياغة الفرض الإحصائي

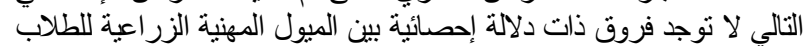

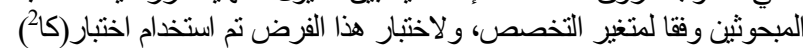

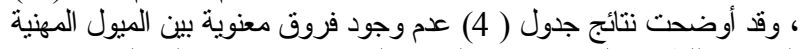

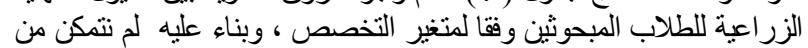

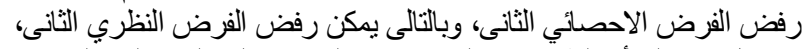

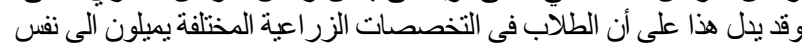

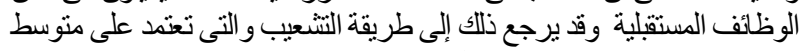

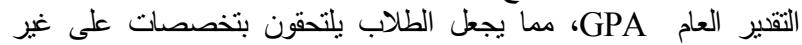

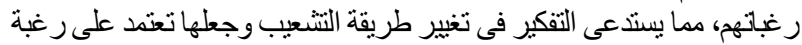
وميول الطلاب بالإضافة إلى GPA الخاص بهم.
تابع جلول 2. معلملات الآسلق الداخلى لعبارات مقيس الميول المهنية الزيراعية

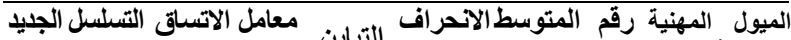

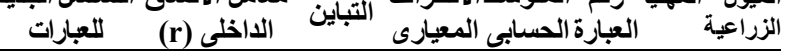

$24 \quad * * 0,846 \quad 0,134 \quad 0,366 \quad 2,8 \quad 32$

$25 \quad 0,0 \quad 0,0 \quad 0,0 \quad 33$

ميل الأفراد $26 \quad * * 0,736 \quad 0,095 \quad 0,30 \quad 2,9 \quad 34$

لامتلاك

مشروعات 27

صغيرة 28

$29 \quad * 0,542 \quad 0,095 \quad 0,30 \quad 2,9 \quad 38$

$\begin{array}{llllll}30 & 0,0 & 0,0 & 0,0 & 39 \\ 31 & & 0,636 & 0,095 & 0,30 & 2,9\end{array}$

$31 \quad * * 0,636 \quad 0,095 \quad 0,30 \quad 2,9 \quad 40$

ميل الأفراد 32

$33 \quad * * 0,911 \quad 0,134 \quad 0,366 \quad 2,8 \quad 42 \quad$ للإعمل

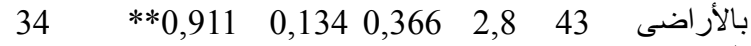

$35 \quad * * 0,795 \quad 0,050 \quad 0,22 \quad 2,9 \quad 44 \quad$

$36 \quad * * 0,896 \quad 0,95 \quad 0,30 \quad 2,9 \quad 45$

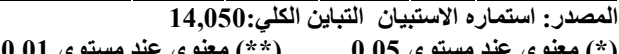

ثانيا: الفروق بين الطلاب المبحوثين وفقا للميول المهنية الزراعية الأكثر انتشارا

أـالفروق بين الميول المهنية الزراعية للطلاب المبحوثين وفقا لمتغير التوع:

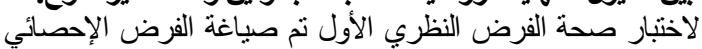

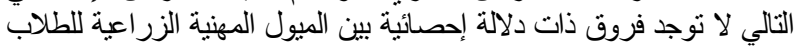

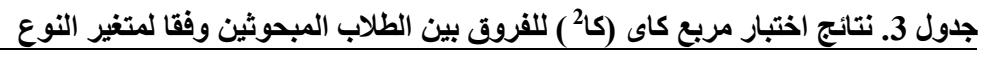

\begin{tabular}{|c|c|c|c|c|c|c|}
\hline \multirow{3}{*}{ المغنوية } & \multirow{3}{*}{ كيا2 } & \multicolumn{4}{|c|}{ 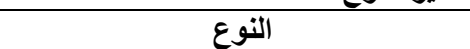 } & \multirow{3}{*}{ الميول المهنية الزراعية } \\
\hline & & \multicolumn{2}{|c|}{ 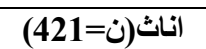 } & \multicolumn{2}{|c|}{ ذكور(ن=|119) } & \\
\hline & & $\%$ & عدد & $\%$ & عدد & \\
\hline \multirow{6}{*}{0,6} & \multirow{6}{*}{3,4} & 6,2 & 26 & 5,0 & 6 & ميل الأفر اد للعمل فى القطاع الزر اعى الحكومى. \\
\hline & & 35,6 & 150 & 36,1 & 43 & ميل الأفر اد للعمل \\
\hline & & 17,5 & 74 & 23,5 & 28 & ميل الأفر اد للعمل بالمجال البحثَى بالجامعات و المر اكز البحثية \\
\hline & & 12,6 & 53 & 8,4 & 10 & ميل الأفر اد للعمل بمجال الإرشاد وخدمة المجتمع و البيئة. \\
\hline & & 23,3 & 98 & 21,8 & 26 & ميل الأفر اد لامتلاك مشرو عات صغيرة. \\
\hline & & 4,8 & 20 & 5,0 & 6 & ميل الأفر اد للعمل بالأر اضى الزر اعية. \\
\hline
\end{tabular}

جدول 4. نتائج اختبار مربع كاى (كا2) للفروق بين الطلاب المبحوثين وفقا لمتغير التخصص

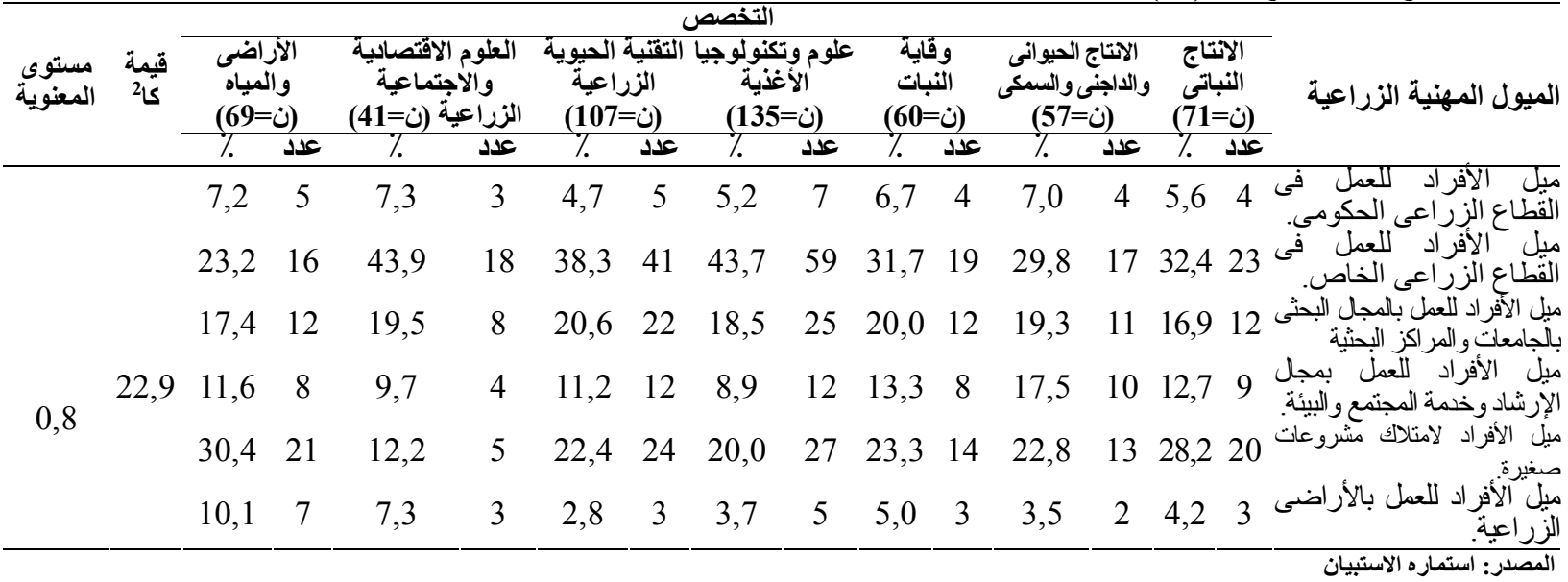

إقامة الأفراد سواء فى ريف أو حضر لا تؤثر فى اختيار اتهم المهنية

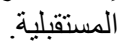

دالفروق بين الميول المهنية الزراعية للطلاب المبحوثين وفقا لمتغير امتلاك أرض زراعية من عدمه:

لاختبار صحة الفرض النظري الرابع نم صياغة الفرض الإحصائي

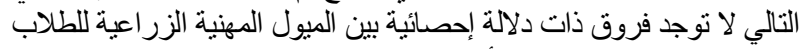

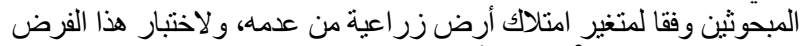

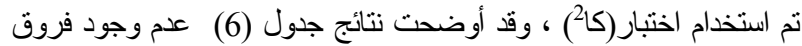
معنوية بين الميول المهنية الزراعية للطلاب المبحوثين وفقال لمتغير امتلاك
ج-الفروق بين الميول المهنية الزراعية للطلاب المبحوثين وفقا لمتغير الائير

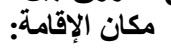

لاختبار صحة الفرض النظري الثالث نم صياغة الفرض الفرض

الإحصائي التالي لا توجد فروق ذات دلات دلالة إحصائية بين الميول المهنية

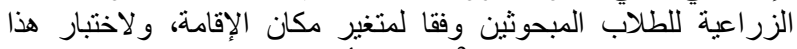

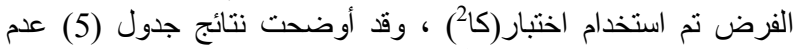

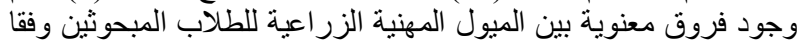

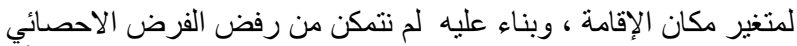

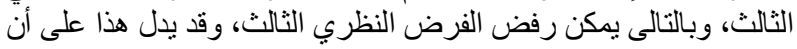




\section{Raghda H. M. Salem}

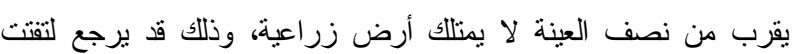
الحيازات الزر اعية والبناء على الأراضى الزئ أرضية.

أرض زر اعية من عدمه ، وبناء عليه لم تنتكن من رفض الفرض الترب الاحصائي

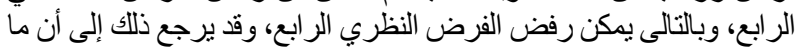

جدول 5. نتائج اختبار مربع كاى (كا2) للفروق بين الطلاب المبحوثين وفقا لمتغير مكان الاقامة مكان الاقامة - مكانة

\begin{tabular}{|c|c|c|c|c|c|c|}
\hline \multirow{3}{*}{\multicolumn{2}{|c|}{ قيمة كا2 مستوى المعنوية }} & \multicolumn{4}{|c|}{ مكان الاقامة } & \multirow{3}{*}{ الميول المهنية الزراعية } \\
\hline & & \multicolumn{2}{|c|}{ المدينة (ن=236) } & \multicolumn{2}{|c|}{ الريف (ن=304) } & \\
\hline & & $\%$ & عدد & $\%$ & عداد & \\
\hline \multirow{6}{*}{0,9} & \multirow{6}{*}{1,5} & 5,5 & 13 & 6,25 & 19 & ميل الأفر اد للعمل في القطاع الزر اعى الحكومى. \\
\hline & & 34,7 & 82 & 36,5 & 111 & ميل الأفر اد للعمل فى القطاع الزر اعى الخاص. \\
\hline & & 19,5 & 46 & 18,4 & 65 & ميل الأفر اد للعمل بالمجال البحثى بالجامعات والمر اكز البحثية \\
\hline & & 10,6 & 25 & 12,5 & 38 & ميل الأفر اد للعمل بمجال الإرشاد وخدمة المجتمع و البيئة. \\
\hline & & 25,0 & 59 & 21,4 & 65 & ميل الأفر اد لامتلاك مشرو عات صغيرة. \\
\hline & & 4,6 & 11 & 4,9 & 15 & ميل الأفر اد للعمل بالأراضى الزر اعية. \\
\hline
\end{tabular}

جدول 6. نتائج اختبار مربع كاى (كا2) للفروق بين الطلاب المبحوثين وفقا لمتغير امتلاك أرض زراعية من عدمه

\begin{tabular}{|c|c|c|c|c|c|c|}
\hline \multirow{3}{*}{ مستوى المعنوية } & \multirow{3}{*}{ قيمة كا2 } & \multicolumn{4}{|c|}{ امتلاك أرض زراعية } & \multirow{3}{*}{ الميول المهنية الزراعية } \\
\hline & & 306=ن & $\gamma$ & $234=\dot{0}$ & ن انعم & \\
\hline & & $\%$ & عدد & $\%$ & عدد & \\
\hline \multirow{6}{*}{0,9} & \multirow{6}{*}{1,1} & 5,6 & 17 & 6,4 & 15 & ميل الأفر اد للعمل فى القطاع الزر اعى الحكومى. \\
\hline & & 34,3 & 105 & 37,6 & 88 & ميل الأفر اد للعمل فى القطاع الزر اعى الخاص. \\
\hline & & 19,3 & 59 & 18,4 & 43 & ميل الأفر اد للعمل بالمجال البحثى بالجامعات و المر اكز البحثية \\
\hline & & 11,8 & 36 & 11,5 & 27 & ميل الأفر اد للعمل بمجال الإرشاد وخدمة المجتمع والبيئة. \\
\hline & & 24,2 & 74 & 21,4 & 50 & ميل الأفر اد لامتلاك مشروعات صغيرة. \\
\hline & & 4,9 & 15 & 4,7 & 11 & ميل الأفر اد للعمل بالأر اضى الزر اعية. \\
\hline
\end{tabular}

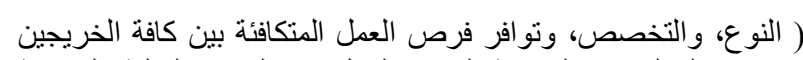

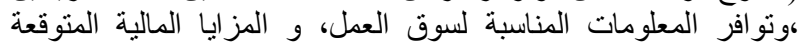

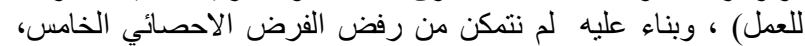

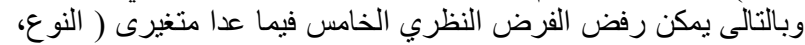

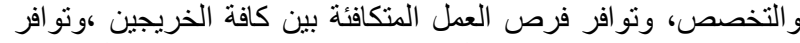

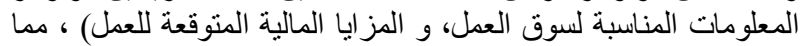

يستدعى تفعيل إجر اءات عاجلة وفعالة لتحسين البيئة الداخلية (التعليمية).

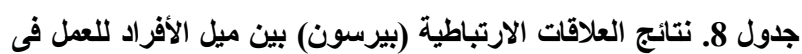

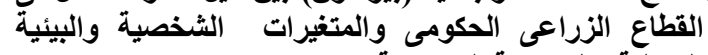
الاخلية والخارجية المدروسى الزكاعة

\begin{tabular}{|c|c|}
\hline قيم معاملات الارتباط لبيرسون & المدروسيرات \\
\hline & أـالمتغير ات الشخصية \\
\hline$* 0,087$ & 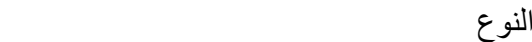 \\
\hline$* 0,095$ & 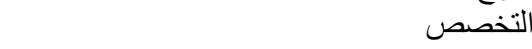 \\
\hline$-0,018$ & 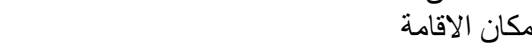 \\
\hline 0,003 & امتلاك أرض زر اعية من عدمه \\
\hline & ب_المتغير ات البيئية الداخلي \\
\hline 0,066 & تو افر المناهج الدر اسية الملاءمة لسوق العمل. \\
\hline 0,052 & تو افر الامكانيات التعليمية المادية المناسبة. \\
\hline 0,023 & الإمكانيات التعليمية البشرية المناسبة. \\
\hline 0,067 & الدور ات التدرييية الملاعمة لسوق العمل. \\
\hline 0,064 & العلاقات الطلابية الجامعية. \\
\hline & ج-المتغيرات البيئية الخارجي \\
\hline$* 0,106$ & تو افر فرص العمل المتكافئة بين كافة الخريجين. \\
\hline$* 0,109$ & لَو افر المعلومات المناسبة لسوق العمل \\
\hline$* 0,166$ & المز ايا المالية المتوقعة للعمل \\
\hline 0,04 & تو افر الظروف الاقتصادية والسياسية المناسبة \\
\hline 0,031 & لامتثال للمعليير السائدة فى المجتمع ( نظره المجتمع للعمل). \\
\hline & " * معنوي عند \\
\hline
\end{tabular}

بـ العلاقة بين ميل الأفراد للعمل فى القطاع الزراعي الخاص والعوامل

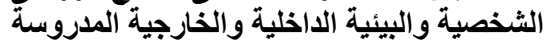

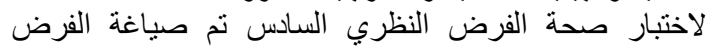

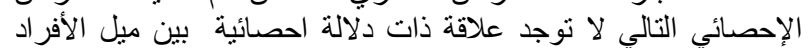
للعمل فى القطاع الزر اعى الخاص و المتغير ات الثخدية التخية والبيئية الداخلية
هـفضيلات الطلاب المبحوثين للميول المهنية الزراعية المدروسة:

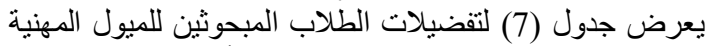

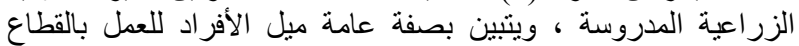

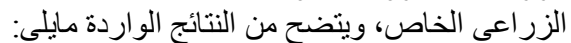

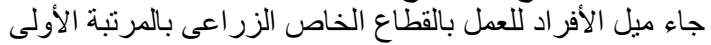

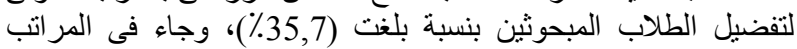

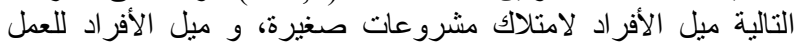

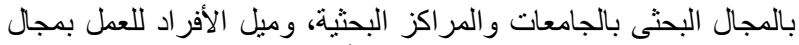

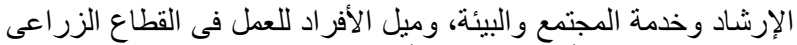

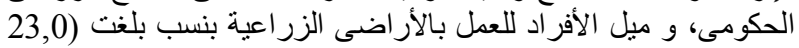

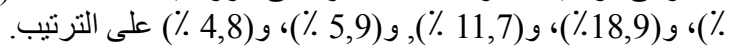

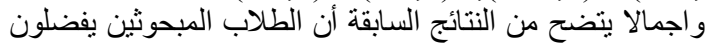

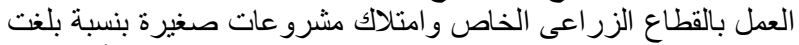

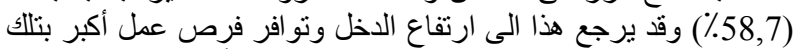

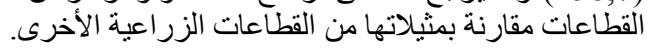

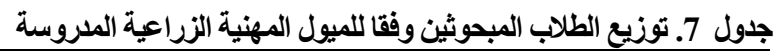

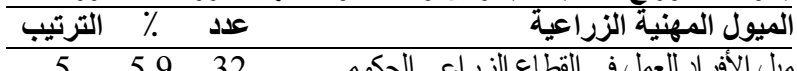

ميل الأفر اد للعمل في القطاع الزعلئ الزر اعى الحكومى.

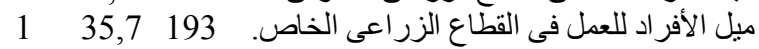

ميل الأفر اد للعمل بالمجل البحثى بالجامعات والمبل المر اكز البحثية $102 \quad 18,9$

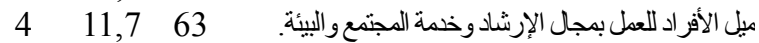

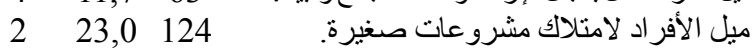

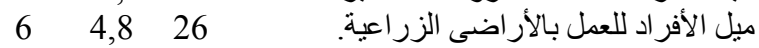
المصدر: استمارات الاستبيان ثالثا: العلاقة بين الميول المهنية الزراعية والعوامل العلان الثخصية والبيئية

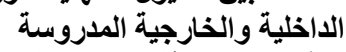
أـ العلاقة بين ميل الأفراد للعمل فيل القدرة القطاع الزراعى الحكومى والعوامل

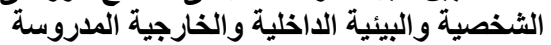

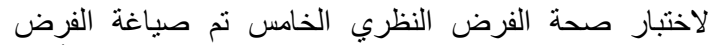

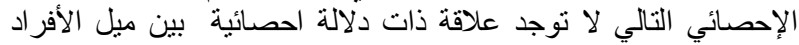

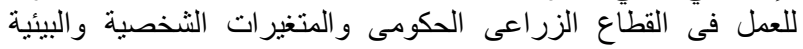

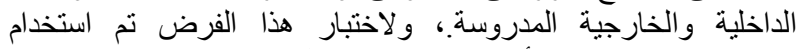

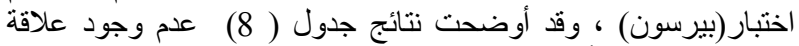

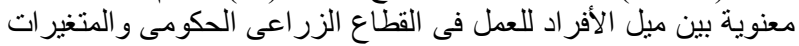
الثخصية والبيئية الداخلية والخارجية المدروسة فيلة فيما عدا متغيرى الزئي 


\section{J. Agric. Econom. and Social Sci., Mansoura Univ., Vol. 9(4), April, 2018}

و المتغير ات الثخصية والبيئية الداخلية والخارجية المدروسة فيما عدا

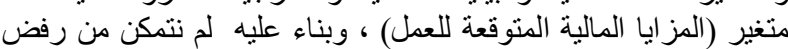

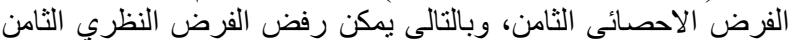

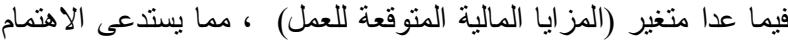

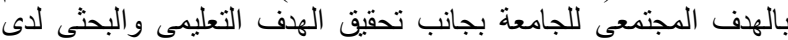

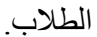

جدول 10. نتائج العلاقات الارتباطية (بيرسون) بين ميل الأفراد للعمل

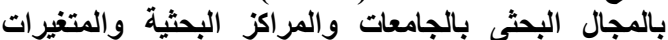

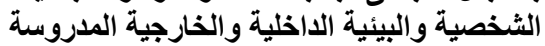

\begin{tabular}{|c|c|}
\hline قيم معاملات الارتباط لبيرسون & المدتغيرات المدوسة \\
\hline & أ_المتغير ات الشخصية \\
\hline$-0,067$ & 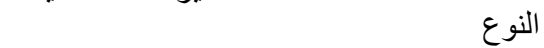 \\
\hline$-0,002$ & 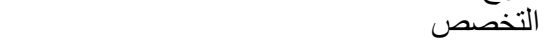 \\
\hline$-0,048$ & مكان الاقامة \\
\hline 0,001 & امتلاك أرض زر اعية من عدمه \\
\hline & ب_المتغير ات البيئية الداخلية \\
\hline$* 0,101$ & تو افر المناهج الدراسية الملاءمة لسوق العمل. \\
\hline 0,001 & تو افر الامكانيات التعليمية المادية المناسبة. \\
\hline$-0,008$ & الإمكانيات التعليمية البشرية المناسبة. \\
\hline$*, 090$ & الدور ات التدريبية الملاعمة لسوق العمل. \\
\hline$* * 0,12$ & العلاقات الطلابية الجامعية. \\
\hline & ج-المتغير ات البيئية الخارجيةً \\
\hline 0,050 & تو افر فرص العمل المتكافئة بين كافة الخريجين. \\
\hline 0,076 & تو افر المعلومات المناسبة لسوق العمل \\
\hline 0,037 & المز ايا المالية المتوقعة للعمل \\
\hline$-0,016$ & تو افر الظروف الاقتصادية والسياسية المناسبة \\
\hline$* 0,090$ & الامتثال للمعايير الساتدة فى المجتمع ( نظره المجتمع للعمل). \\
\hline & " * معنوي عند \\
\hline
\end{tabular}

جدول 11. نتائج العلاقات الارتباطية (بيرسون) بين ميل الأفراد للعمل

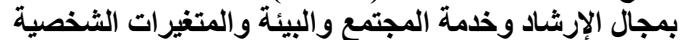

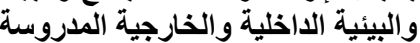

\begin{tabular}{|c|c|}
\hline قيم معاملات الارتباط لبيرسون & المدروسيرات \\
\hline & أـالمتغير ات الثخصبة \\
\hline 0,02 & 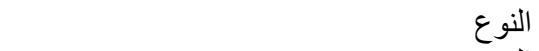 \\
\hline 0,005 & 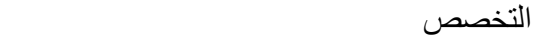 \\
\hline$-0,055$ & 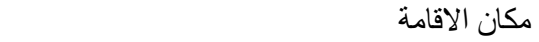 \\
\hline 0,022 & امتلآك أرض زر اعية من عدمه \\
\hline & ب_المتغير ات البيئية الداخليا \\
\hline 0,064 & تو افر المناهج الدر اسية الملاءمة لسوق العمل. \\
\hline 0,04 & تو افر الامكانيات التعليمية المادية المناسبة. \\
\hline 0,015 & الإمكانيات التعليمية البشرية المناسبة. \\
\hline 0,063 & الدور ات التدريبية الملاءمة لسوق العمل. \\
\hline 0,017 & العلاقات الطلابية الجامعية. \\
\hline & ج-المتغيرات البيئية الخارجي \\
\hline$-0,008$ & تو افر فرص العمل المتكافئة بين كافة الخريجين. \\
\hline 0,043 & تو افر المعلومات المناسبة لسوق العمل \\
\hline$* 0,101$ & المز ايا المالية المتوقعة للعمل \\
\hline 0,062 & تو افر الظروف الاقتصادية و السياسية المناسبة \\
\hline 0,058 & الامتثال للمعايير السائدة فى المجتمع ( نظره المجتمع للعمل). \\
\hline & تمار ات الاستبيان معنوي عند \\
\hline
\end{tabular}

هـ ـالعلاقة بين ميل الأفراد لامتلاك مشروعات صغيرة والعوامل

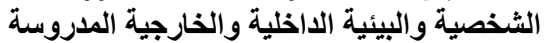

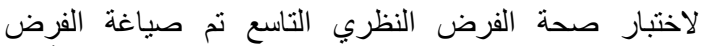

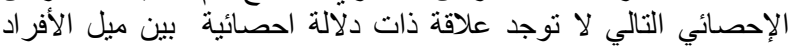

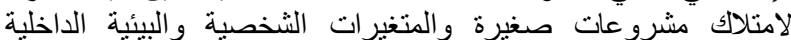

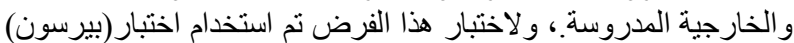

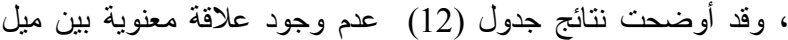

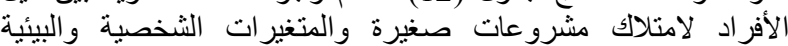

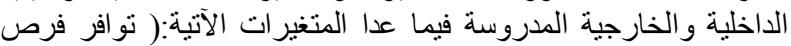

و الخارجية المدروسة.، و لاختبار هذا الفرض تم استخدام اختبار(بيرسون)

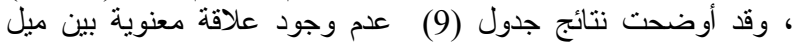

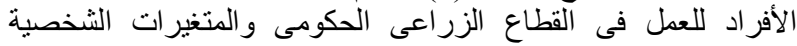

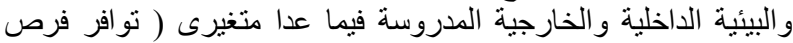

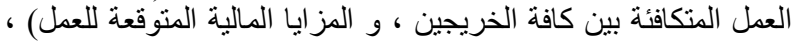

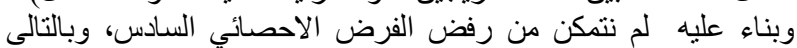

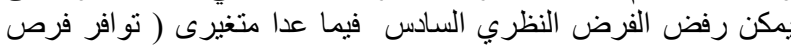

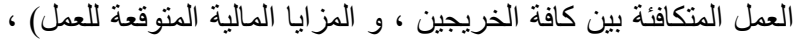

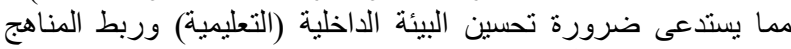

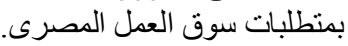

جدول 9. نتائج العلاقات الارتباطية (بيرسون) بين ميل الأفراد للعمل في

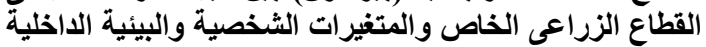

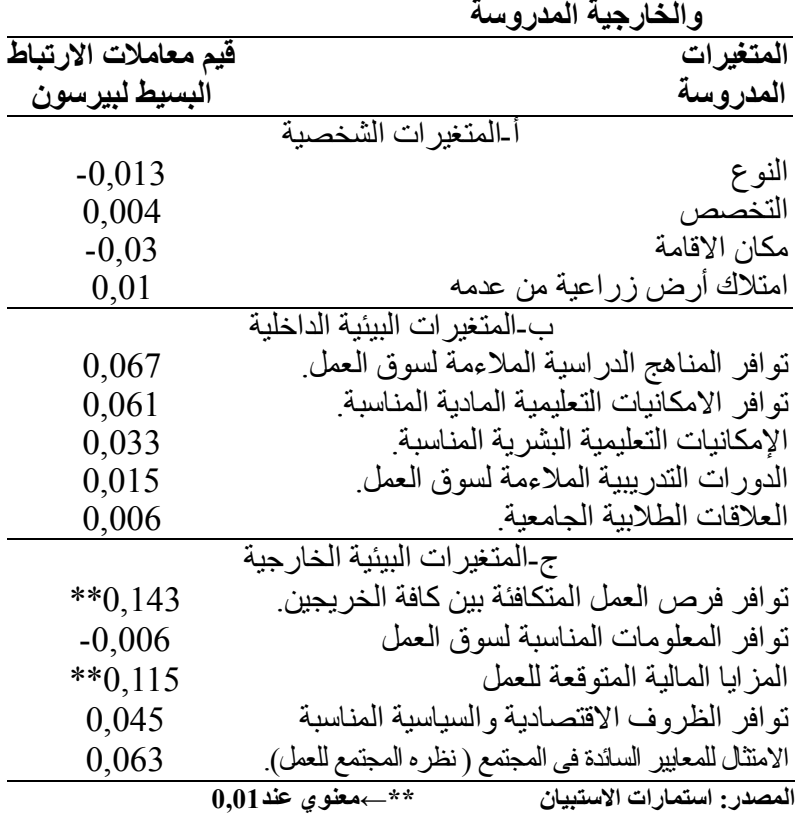

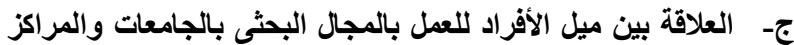

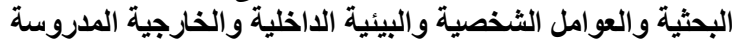

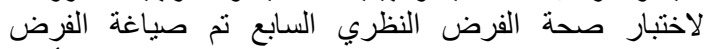

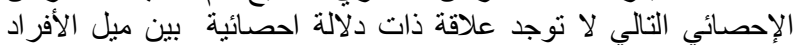

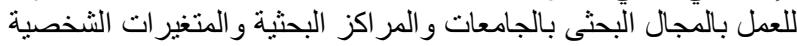

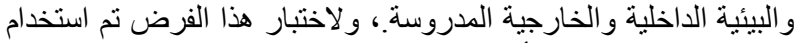

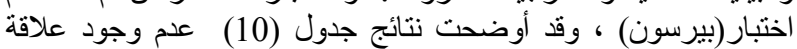

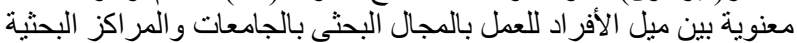

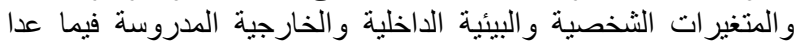

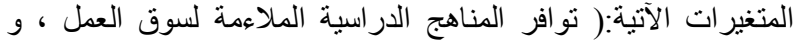

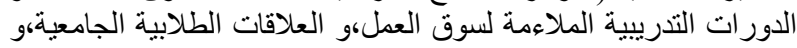

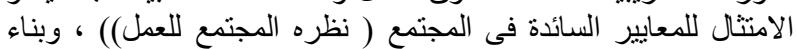

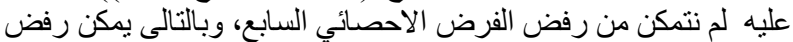

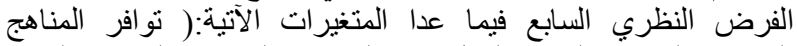

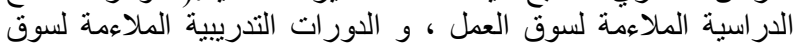

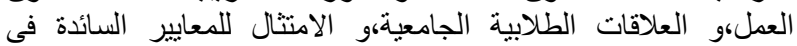

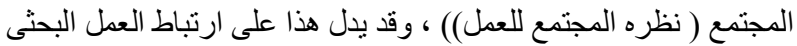

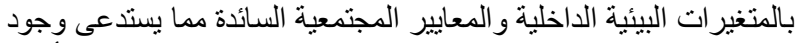

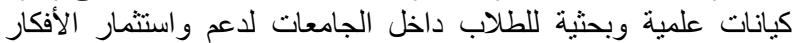

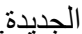

دـ العلاقة بين ميل الأفراد للعمل بمجال الإرشاد وخدمة المجتمع والبيئة

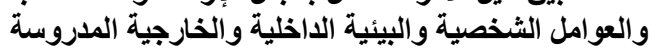

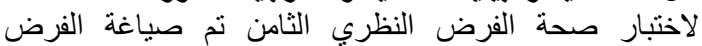

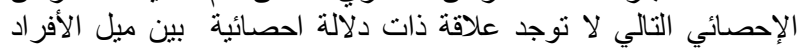

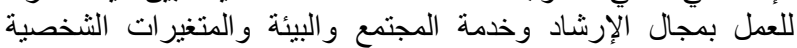

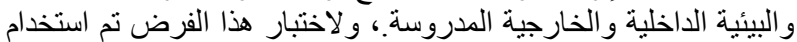

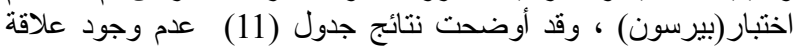
معنوية بين ميل الأفراد للعمل بمجال الإرشاد وخدمة ولترل المجتمع والبيئة 
وقد يدل هذا على أهمية المتغيرات المدروسة سواء الثخصية أو البيئية

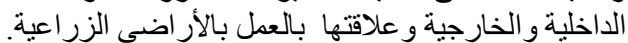
رابعا: اقتراح إجراءات لمواجهه المشكلات المستقبلية لحصول الماتية الطلاب

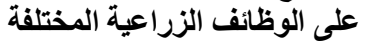

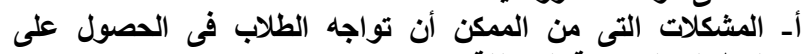
الوظائف الزراعية المختلفة المن المن المن

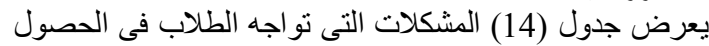

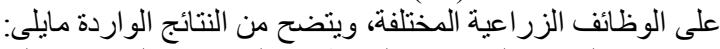

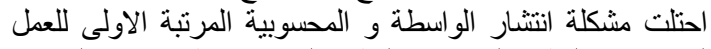

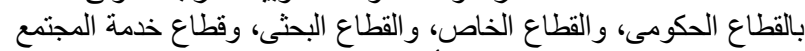

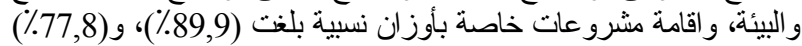

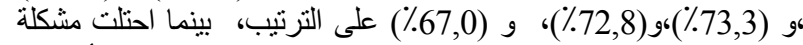

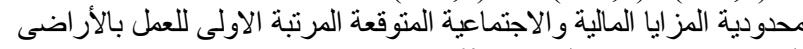

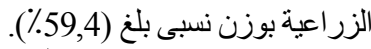
واجمالا يتضح من النتائج السابقة أن أكثر المشكلات المنتشرة

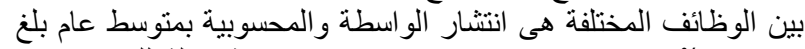

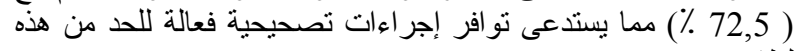

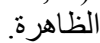

جدول 13. نتائج العلاقات الارتباطية (بيرسون) بين ميل الأفراد للعمل

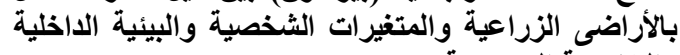

\begin{tabular}{|c|c|}
\hline قيم معاملات الارتباط لبيرسون & المتغنيرات المروسة \\
\hline & أ_المتغير ات الثخصية \\
\hline$* *-0,122$ & 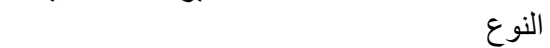 \\
\hline$-0,049$ & التخصص \\
\hline$* * 0,123$ & 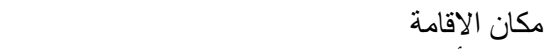 \\
\hline$* * 0,127$ & امتلاك أرض زر اعية من عدمه \\
\hline & بــالمتغير ات البيئية الداخلية \\
\hline$* * 0,209$ & تو افر المناهج الدر اسية الملاعمة لسوق العمل. \\
\hline$* * 0,144$ & تو افر الامكانيات التعليمية المادية المناسبة. \\
\hline$* * 0,151$ & الإمكانيات التعليمية البشرية المناسبة. \\
\hline$* * 0,220$ & الدور ات التدريبية الملاءمة لسوق العمل. \\
\hline$* * 0,119$ & العلاقات الطلابية الجامعية. \\
\hline & ج-المتغيرات البيئية الخارجية \\
\hline$* * 0,132$ & تو افر فرص العمل المتكافئة بين كافة الخريجين. \\
\hline$* * 0,211$ & تو افر المعلومات المناسبة لسوق العمل \\
\hline$* * 0,183$ & المز ايا المالية المتوقعة للعمل \\
\hline$* * 0,156$ & تو افر الظروف الاقتصادية و السياسية المناسبة \\
\hline$* * 0,156$ & الامتثال للمعايير السائدة فى المجتمع ( نظره المجتمع للعمل). \\
\hline & 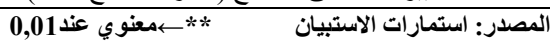 \\
\hline
\end{tabular}

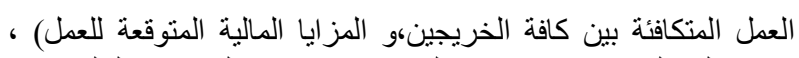

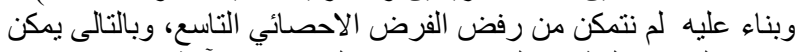

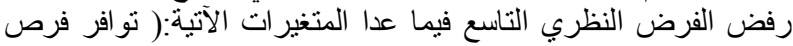

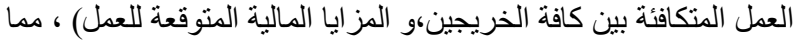

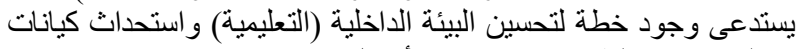
بها لدعم توجه الطلاب نحو رجو ريادة الأعمال.

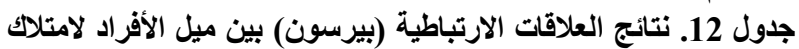

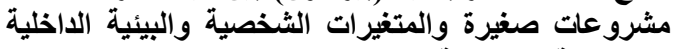

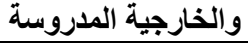

\begin{tabular}{|c|c|}
\hline قيم معاملات الارتباط لبيرسون & المدروسيرات \\
\hline & أ_المتغير ات الثخصية \\
\hline$-0,052$ & 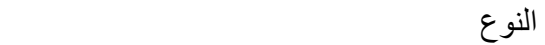 \\
\hline$-0,033$ & التخصص \\
\hline 0,00 & 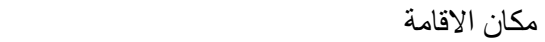 \\
\hline$-0,033$ & امتلاك أرض زر اعية من عدمه \\
\hline & ب_المتغير ات البيئية الداخلية \\
\hline 0,067 & تو افر المناهج الدر اسية الملاءمة لسوق العمل. \\
\hline 0,049 & تو افر الامكانيات التعليمية المادية المناسبة. \\
\hline 0,029 & الإمكانيات التعليمية البشرية المناسبة. \\
\hline 0,058 & الدور ات التدرييية الملاءمة لسوق العمل. \\
\hline 0,012 & العلاقات الطلابية الجامعية. \\
\hline & ج-المتغير ات البيئية الخارجيا \\
\hline$* * 0,13$ & تو افر فرص العمل المتكافئة بين كافة الخريجين. \\
\hline 0,066 & تو افر المعلومات المناسبة لسوق العمل \\
\hline$* * 0,163$ & المز ايا المالية المتوقعة للعمل \\
\hline 0,056 & تو افر الظروف الاقتصادية و السياسية المناسبة \\
\hline 0,048 & الامنثل للمعايير السائدة فى المجتمع ( نظره المجتمع للعمل). \\
\hline & 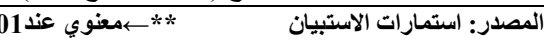 \\
\hline
\end{tabular}

و-العلاقة بين ميل الأفراد للعمل بالأراضى الزراعية والبيئية الاخلية والخارجية المدروسة ميلة الافرات

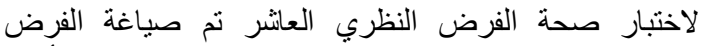

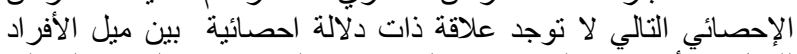

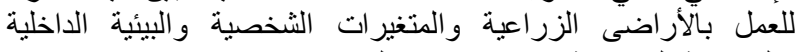

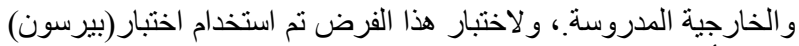

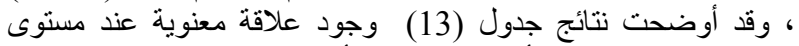

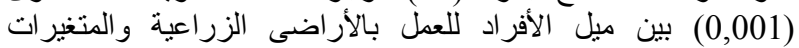

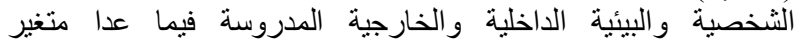

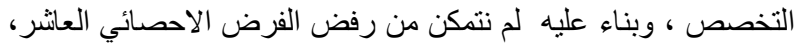

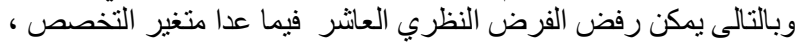

جدول 14. المشكلات المستقبلية المتوقع أن تواجه الطلاب المبحوثين فى الحصول على الوظائف الزراعية المختلفة

\begin{tabular}{|c|c|c|c|c|c|}
\hline الاستمرارية في العمل & علم توافر الخبرات والمهارات العمل العبوت & وحدودية المزايا المالية & واللوائح المنظمة للعمة القوانين & انتثار الواسطة & الوظائ \\
\hline الوزن النسبي (٪) & الوزن النسبي (\%) & الوزن النسبي (\%) & الوزن النسبى (\%) & الوزن النسبي (٪) & \\
\hline 62,3 & 75,5 & 73,8 & 76,9 & 89,9 & ـالعمل بالقطاع الحكومى \\
\hline 74,01 & 64,4 & 67,2 & 68,3 & 77,8 & ـالعمل بالقطاع الخاص \\
\hline 65,2 & 65,4 & 49,01 & 66,2 & 73,3 & ـالعمل بالقطاع البحثي \\
\hline 65,8 & 65,1 & 66,2 & 68,4 & 72,8 & ـالعطل بقطاع خذمة المجتمح \\
\hline 64,2 & 63,2 & 66,7 & 66,2 & 67,0 & ـاقامة مشرو عات خاصة \\
\hline 55,3 & 57,1 & 59,4 & 56,5 & 54,3 & ـالعمل بالأر اضى الزر اعية \\
\hline 64,5 & 65,1 & 63,7 & 67,1 & 72,5 & المتوسط العام \\
\hline
\end{tabular}

بـالسياسات المقترحة لحل تلك المشكلات (مجتمعية، تعليمية ، توظيفية، تشريعية). ج-الجهات والمؤسسات المسئولة عن حل تلاتلك المشكلات (الأسرة و المدرسة، الجامعة، جهات التوظيف الزولة الزر اعية، الحكومة)
ب_الإجراءات المقترحة لمواجهه المشكلات المستقبلية لحصول الطلاب على الوظائف الزراعية المخترهة المواعلفة

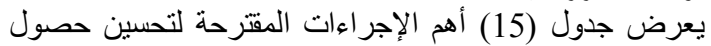

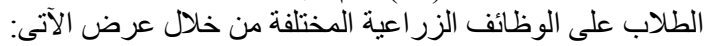

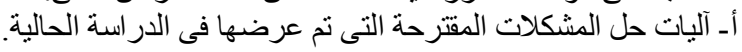


جدول 15. الإجراءات المقترحة لمواجهه المشكلات المستقبلية لحصول الطلاب على الوظائف الزراعية المختلفة

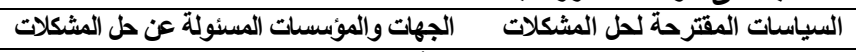

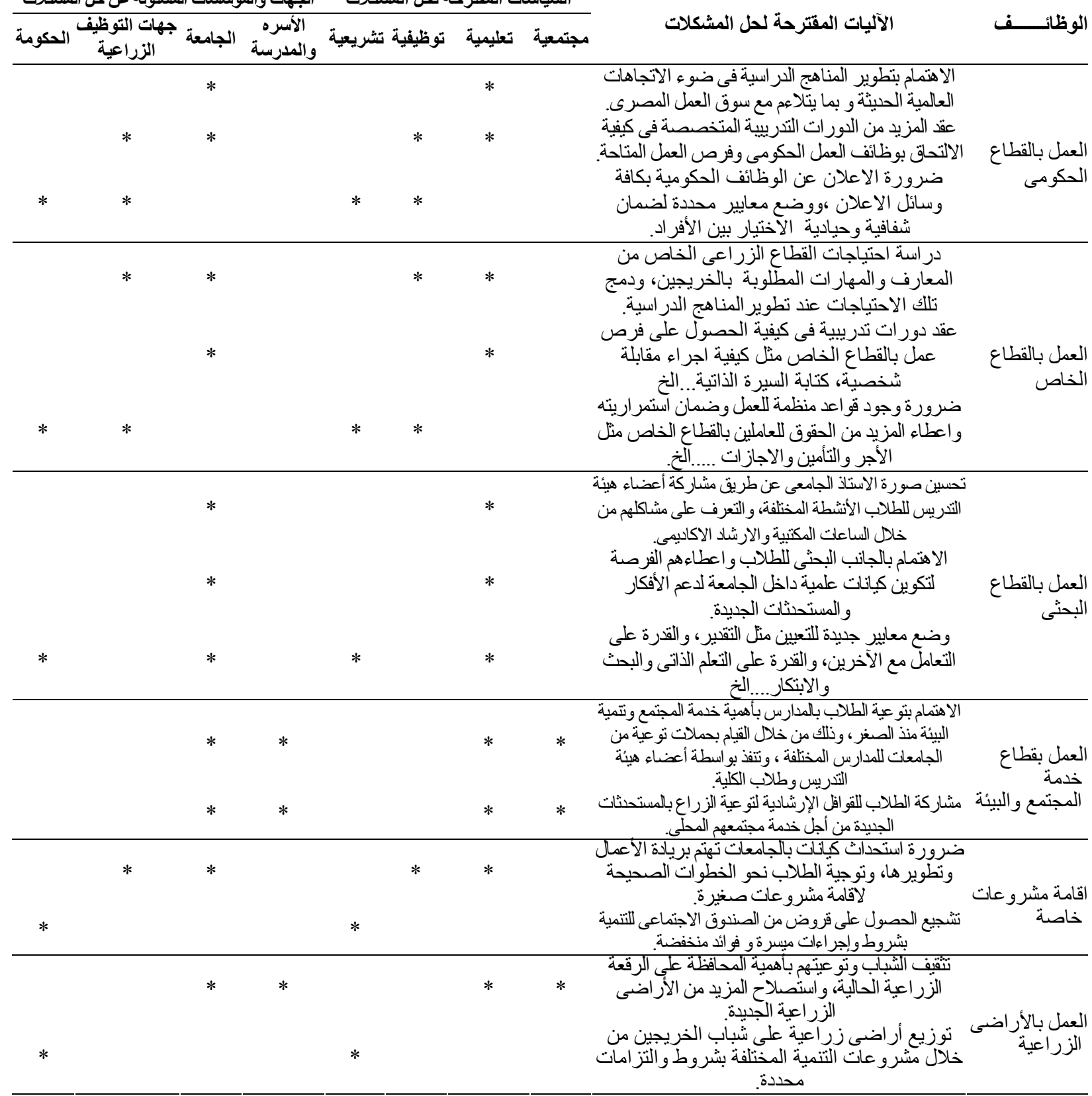

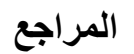

إبر اهيم,محسن درغام (2012): الميول المهنية لدى عينة من طلبة الدانة

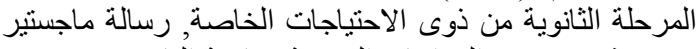

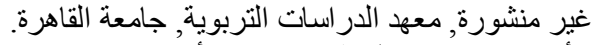

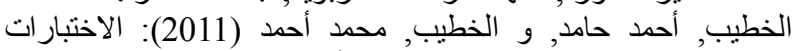

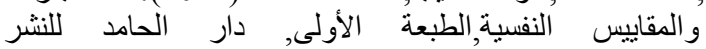
و التوزيع, عمان , الأردن.

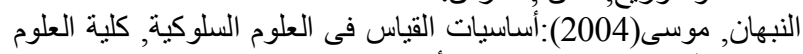
التربوية, جامعة مؤتة, الأردن.

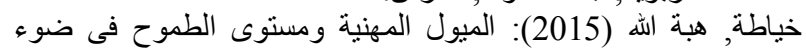

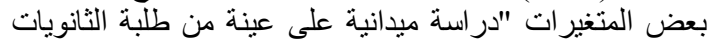

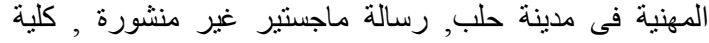
التربية, جامعة حلب.

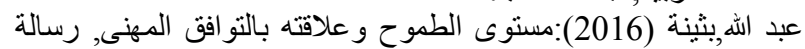
ماجستير غير منشورة, كلية العلوم الانسانية والاجنماعية, جامعة التونة محمد خيضر, الجز ائر.

\section{المصدر: نتائج الاراسة الحالية}

الاستتتاجات الرئيسية

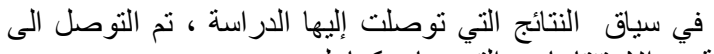

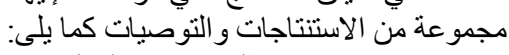

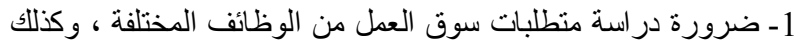

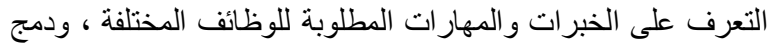
تللك المتطلبات عند وضع المقرات ولهرات الدرات الدراسية والبرامج التدرييية بالجامعات المختلفة.

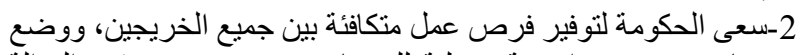

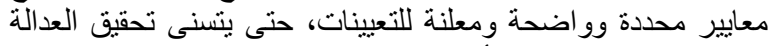
الاجتماعية والمساو اة بين أفر اد المجتمع كافة.

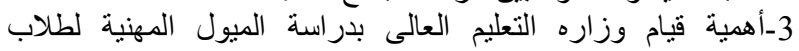

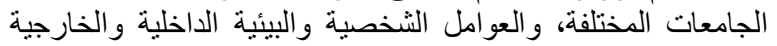

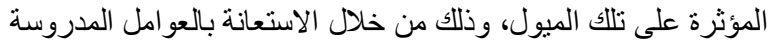

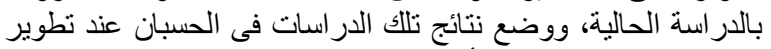

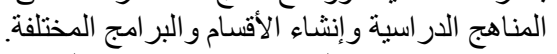

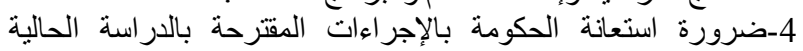
لتحسين حصول الخريجين على الوظائف الزر اعية المختلفة. 


\section{Raghda H. M. Salem}

Chemeli,S.P.(2013): An Assessment of the Relationship between Students' Personality Types and Career Aspirations in Eldoret West District, Kenya, Journal of Emerging Trends in Educational Research and Policy Studies, Vol.(4),No.(2),pp.338-391.

Kemboi,R.J.; Kindiki,N. \& Misigo,B. (2016): Relationship between Personality Types and Career Choices of Undergraduate Students: A Case of Moi University, Kenya, Journal of Education and Practice, Vol.(7),No.(3),pp.102-112.

Nauta,M.,M.(2010): The Development, Evolution, and Status of Holland's Theory of Vocational Personalities: Reflections and Future Directions for Counseling Psychology, Journal of Counseling Psychology, Vol.(57),No.(1),pp.11-22.

Ohiwerei,F.O\& Nwosu,B.O (2009): Vocational Choices among Secondary School Students: Issues and Strategies in Nigeria, Asian Journal of Business Management, Vol.(1),No.(1),pp.1-5.

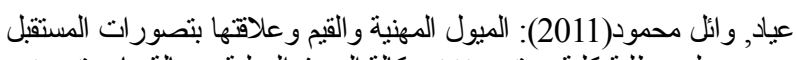

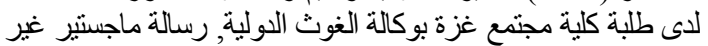
منشورة ,كلية التربية,جامعة الأزية هربغزة

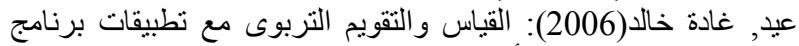

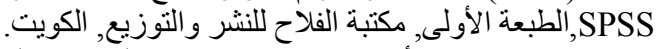

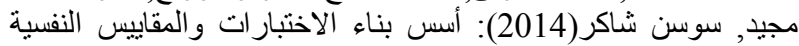

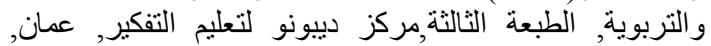
الأردن.

مقداد, محمد (2014): أنماط الشخصية وعلاقتها بالميول المهنية لدى الثى

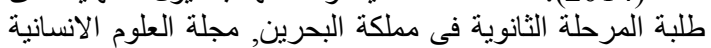

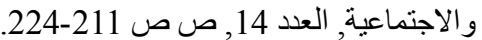

وزارة الزراعة واستصلاح الأراضي الزئل (2009): استراتيجية التنمية

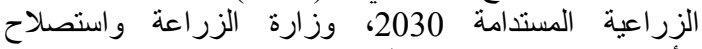
الأر اضي، جمهورية مصر العربية.

Aljojo,N.(2016): Choosing a Career Based Personality Matching: A Case Study of King Abdulaziz University, International Journal of Advanced Computer Science and Applications, Vol.(7),No. (2),pp.215-221.

ملحق الميول 
An Analytical Study of Agricultural Vocational Tendencies and their Relationship to some Personal and Environmental Factors (A Study for Students of the Faculty of Agriculture, Mansoura University)

Raghda H. M. Salem

Department of Agricultural Extension and Rural Society, Faculty of Agriculture, Mansoura University

\begin{abstract}
The current study aimed mainly to identify some of the personal, social and environmental factors and their impact on the agricultural vocational tendencies of students of the Faculty of Agriculture Mansoura University by achieving the following sub-objectives :1-Building a scale of agricultural vocational tendencies with a high degree of validity and reliability. 2- Identifying the differences between students according to the most prevalent agricultural vocational tendencies. 3-To Identify the relationship between agricultural vocational tendencies ,personal and internal and external environmental factors. 4To Suggest procedures to face the future problems of students access to various agricultural jobs. A systematic random sample of 540 students was selected. The data were collected during the first semester of the academic year 2017-2018 through questionnaire based on personal interview. Frequency, percentages, arithmetic mean, standard deviation, variance, validity and reliability coefficient, Chi-Square test, and Pearson correlation coefficient were used as tools for statistical analysis and presentation of study results. The results of the study were summarized as follows: 1-The results of agricultural vocational tendencies scale showed that it consisted of (36) words of high degree of validity and reliability. 2-The results showed that the students prefer to work in the agricultural private sector by $35.8 \%$.3- There were significant correlations between agricultural vocational tendencies and some personal and environmental variables $(\mathrm{P}<0.01)$, $(\mathrm{P}<0.05)$. 4-Finally, results showed that the most important problems facing students in obtaining various agricultural jobs were the spread bias and favoritism by $72.5 \%$.
\end{abstract}

